Monika Milewska

ORCID: https://orcid.org/0000-0002-0434-8771

Uniwersytet Gdański

Instytut Archeologii i Etnologii

\title{
Stołówki w przestrzeni socjalistycznego miasta
}

\section{Canteens in the space of a socialist city}

\begin{abstract}
In the People's Republic of Poland a workplace, along with its social infrastructure meeting most of the basic needs of employees, was to be an alternative space to the city. Canteens, which were to feed the employees rationally, increasing work efficiency and freeing women from household chores, played a key role here. This project failed, partly also for reasons related to the space of the canteens themselves: they were unaesthetic, unsanitary and inaccessible to family members.
\end{abstract}

Key words: canteens, food, workers, People's Republic of Poland

Zakład pracy wraz ze swą infrastrukturą socjalną, zaspokajającą większość podstawowych potrzeb pracowników, miał być w PRL-u przestrzenią alternatywną wobec miasta. Kluczową rolę odgrywały tu stołówki, które miały karmić w racjonalny sposób, podnosząc wydajność pracy i uwalniając kobiety od domowych obowiązków. Projekt ten zawiódł, częściowo również z przyczyn związanych z przestrzenią samych stołówek - nieestetyczną, niehigieniczną i niedostępną dla członków rodzin.

Słowa kluczowe: stołówki, jedzenie, robotnicy, Polska Rzeczpospolita Ludowa

Odebrano / Received: 26.03.2021

Zaakceptowano / Accepted: 05.10.2021 


\section{Wstęp}

Zakład pracy w PRL-u to miejsce wydzielone $\mathrm{z}$ przestrzeni miejskiej, warowna forteca strzeżona przez uzbrojoną straż przemysłową, wartowników i portierów. Każde przekroczenie bramy wiązało się z obowiązkiem okazania przepustki, której w każdej chwili można było zostać pozbawionym. Zakładów nie wolno było filmować, fotografować ani nawet szkicować ${ }^{1}$. Za pilnie strzeżonymi murami fabryk, stoczni i hut rozciągały się hektary terenu, zabudowane halami produkcyjnymi, kominami, magazynami. Wśród nich wznoszono obiekty niezwiązane bezpośrednio z produkcją: hotele robotnicze, szpitale, żłobki, pralnie, sklepy... Wielki socjalistyczny zakład pracy szybko obrastał w tkankę miejską, stając się przestrzenią konkurencyjną wobec zewnętrznego świata. Stawal się Miastem.

W skład jego pseudomiejskiej infrastruktury wchodziła sieć żywienia zbiorowego, w której poczesne miejsce zajmowały stołówki. Nazwane przez Lenina „kiełkami komunizmu”, miały dostarczać jedzenie przygotowane zgodnie z najnowszymi ustaleniami nauki i zapewniające wysoką wydajność pracy robotników. Wiązały też pracowników z zakładem i były „narzędziem kontroli zachowań, postaw i rozmów” (Wąchała-Skindzier 2017: 40). Jednocześnie uwalniały kobiety od „kuchennej niewoli” (Głuszczenko 2012: 59, Jarska 2015: 102), zrównywały stołowników i wprowadzały nową proletariacką kulturę (Brzostek 2010: 226). Tak mocno sprzęgnięta z komunistyczną ideologią idea zbiorowego żywienia nie narodziła się jednak w ojczyźnie światowego proletariatu, lecz w Stanach Zjednoczonych, gdzie już w latach 80. XIX wieku zaczęły powstawać w zakładach pracy pierwsze kafeterie, czyli tanie, samoobsługowe stołówki, w których robotnik sam komponował sobie posiłek, przesuwając tacę po metalowej prowadnicy jak po taśmie produkcyjnej (Drzał-Sierocka 2018: 335).

Kolektywne jedzenie $\mathrm{z}$ różnych przyczyn nie stało się w Polsce wzorcem dominującym. Spożywanie obiadu „pozostawało nadal domeną sfery prywatnej. Ważniejszym od racjonalnych argumentów był obyczaj kulturowy, który narzucał kobietom przygotowywanie obiadów w domu" (Mazurek 2005: 247). Częściowo przyczyna leżała też po stronie pracodawcy. Wiele stołówek było zaniedbanych i niedoinwestowanych, a ich pracownicy byli szczególnie nisko uposażeni, co odbijało się na ich stosunku do pracy, a w konsekwencji - na jakości serwowanych posiłków. Stołówkowe obiady były też relatywnie drogie, zwłaszcza dla dyskryminowanych płacowo kobiet, których nie stać było na jednoczesne wykupienie abonamentu dla siebie i zakupienie produktów na obiad dla

\footnotetext{
Mój ojciec, zatrudniony w latach 70. na stanowisku fotografa w Centrum Techniki Okrętowej w Gdańsku, w swoich obowiązkach służbowych miał wykonywanie zdjęć z wodowań statków w Stoczni Gdańskiej. Zgoda na jego wstęp na teren Stoczni, wydana przez Zjednoczenie Przemysłu Okrętowego, przechowywana była w kancelarii tajnej w CTO. Przed każdym wodowaniem ojciec musial pobierać ją stamtąd w asyście swojego przełożonego, a następnie przedkładać ją w celu wydania przepustki na bramie Stoczni. Mimo przepustki na terenie Stoczni poruszał się zazwyczaj w towarzystwie przydzielonego mu strażnika (relacja: 19.05.2021).
} 
reszty rodziny. Pod względem udziału ogółu pracowników w systemie żywienia zbiorowego daleko nam było do wyników osiąganych w „bratnich” krajach. W połowie lat 70 . ze stołówek w Czechosłowacji i na Węgrzech korzystało ponad 30 procent, w NRD ponad 40 procent, a w Związku Radzieckim - aż 75 procent wszystkich pracowników. W tym samym czasie w Polsce odsetek zatrudnionych spożywających swoje obiady w stołówce wynosił zaledwie 7 procent (Czekalski 2011: 81-82).

Temat stołówek w PRL-u nie doczekał się jak dotąd całościowej monografii. W ostatnich dwóch dekadach najwięcej uwagi poświęcili mu w swoich pracach dotyczących różnych kontekstów jedzenia w Polsce Ludowej tacy badacze historii i nauk społecznych, jak Mariusz Jastrząb, Błażej Brzostek, Maria Wąchała-Skindzier, czy Małgorzata Mazurek (Jastrząb 2004, Brzostek 2010, Wąchała-Skindzier 2017, Mazurek 2005, Mazurek 2010). Najbardziej syntetyczne ujęcie zagadnienia prezentuje wciąż jednak artykuł Tadeusza Czekalskiego Przedsiębiorstwa żywienia zbiorowego w realiach PRL: model żywienia zbiorowego w warunkach przyspieszonej modernizacji i jego realizacja (Czekalski 2011). Mój krótki szkic nie pretenduje do roli kolejnej syntezy. Ma on raczej zasygnalizować nową perspektywę badawczą tego zagadnienia - ukazanie typowych przestrzeni stołówek oraz miejsca stołówek w przestrzeni miasta. Kwestie przestrzenne bowiem w niemałym stopniu wpływały na mniejsze lub większe zainteresowanie stołówkami w PRL-u. Liczyły się nie tylko rozmiar, aranżacja i schludność wnętrz jadłodajni, ale także jej lokalizacja względem stanowiska pracy. Istotne w tym kontekście wydają się także sposoby funkcjonowania stołówki w przestrzeni miasta - czy konkurowała ona z gastronomią otwartą, czy dopuszczała stołowanie się osób spoza grona pracowników, w jaki sposób rekompensowany był jej brak na terenie zakładu pracy.

Wgląd w te zagadnienia dadzą nam między innymi pogłębione wywiady kwestionariuszowe przeprowadzone pod moim kierunkiem w latach 2016-2019 przez studentów etnologii Uniwersytetu Gdańskiego. Zawierające 22 pytania wywiady dotyczyły ideologicznych kontekstów jedzenia w PRL-u. Respondenci pochodzili z różnych miast Polski, a ich przekrój zawodowy w interesującym nas okresie był bardzo zróżnicowany. Reprezentowali oni zarówno wielkie przedsiębiorstwa przemysłowe, jak i małe zakłady usługowe, byli wśród nich wojskowi, nie zabrakło też gospodyń domowych. W kwestionariuszu tematu stołówek dotyczyły bezpośrednio trzy pytania - drugie: „Czy respondent korzystał ze stołówki, jeśli nie, to dlaczego? Jakie zachował wspomnienia ze swojej stołówki?”, siódme: „Czy państwo starało się zwalczać tradycje katolickich postów? Jakie dania podawano w Wielki Piątek i Środę Popielcową na stołówkach?” oraz siedemnaste: „Czy respondent pamięta hasła propagandowe na stołówkach, w sklepach spożywczych?”. Jak widać $z$ treści powyższych pytań, kwestie przestrzenne mogły pojawiać tylko na marginesie udzielanych przez respondentów odpowiedzi.

Bazę źródłową artykułu stanowią również moje własne wywiady z pracownicami nowohuckiej gastronomii przeprowadzone w czerwcu 2016 roku oraz prasa. W przypadku tej ostatniej skupiłam się głównie na dwóch dużych centrach przemysłowych: 
Nowej Hucie, w której w latach 1950-1956 wychodziła przeznaczona dla pracowników kombinatu gazeta „Budujemy Socjalizm” (dalej skrót: BS) oraz Trójmieście, w którym ukazywały się skierowane do szerokiego grona odbiorców „Dziennik Bałtycki” (od 1945 roku; dalej skrót DB) i „Wieczór Wybrzeża” (od 1957 roku; dalej skrót: WW). Wybór tych dwóch ośrodków związany był z ich specyficzną sytuacją demograficzną, gdyż do tych właśnie miast napływało $z$ różnych stron Polski wielu młodych mężczyzn, poszukujących pracy w przemyśle metalurgicznym lub stoczniowym. Pozbawieni zaplecza rodzinnego niejako „skazani” byli oni na uczestnictwo w systemie zbiorowego żywienia.

\section{Stołówka w przestrzeni miasta}

Placówki żywienia zbiorowego, zwłaszcza te należące do największych zakładów, nie ograniczały się do wydzielonej sali czy jednego budynku. Przedsiębiorstwa zatrudniające kilkadziesiąt tysięcy pracowników wymagały całych kompleksów, na które składały się - poza typowymi stołówkami - bufety, bary mleczne i sklepy przyzakładowe. W końcu lat 60. Stocznia Gdańska im. Lenina dysponowała 3 stołówkami, 6 barami, 8 bufetami i 7 kioskami spożywczymi (Daszczyńska, Kobzdej 2013: 44). Posiadała też barobus oraz dwie rozdzielnie posiłków na oddziałach. W tym samym czasie na terenie Nowej Huty działało 9 stołówek, 14 barów, 20 kiosków spożywczych, kasyno i kawiarnia. Warszawskie Zakłady Wytwórcze Lamp Elektrycznych im. Róży Luksemburg prowadziły stołówkę i 5 bufetów, a ponadto gotowalnię mleka i kawy oraz kiosk spożywczy (Mazurek 2005: 246). Duże przedsiębiorstwa, zwłaszcza w latach 50., posiadały także własne zaplecze gospodarcze, usytuowane zazwyczaj poza miastem, niekiedy nawet w innym województwie. W jego skład wchodziły pomocnicze gospodarstwa ogrodniczo-warzywnicze, tuczu trzody chlewnej i hodowli bydła. Wspomniane Zakłady im. Róży Luksemburg dysponowały aż dwustuhektarowym gospodarstwem hodowlano-warzywniczym pod Warszawą. Nowa Huta prowadziła dużą wytwórnię wód gazowanych, przetwórnię mięsa i gospodarstwo w Luboczy, gdzie wypasano bydło i sadzono nowalijki. Czasami tego typu zakłady zaopatrywały nie tylko własnych pracowników, ale i resztę miasta. Tak było w przypadku wytwórni wód gazowanych należącej do cukrowni w Strzelinie. W latach 80. z tych zakładowych latyfundiów pozostały zazwyczaj tuczarnie świń, które żywiły się resztkami z robotniczych obiadów.

Stołówka w samym swoim zamyśle konkurowała z przestrzenią prywatną kuchni i jadalni. Nie przynależała jednak do przestrzeni publicznej, której podstawową cechą jest dostępność (Bierwiaczonek 2016: 21). Jak trudno było przeniknąć przez mury zakładu, najlepiej obrazują szpalty gazet zapełnione anonsami o zagubionych przepustkach. Gdy w końcu lat 70. zrodziła się idea, by seniorzy realizowali wydawane im przez Zakłady Opieki Zdrowotnej bony obiadowe w zakładowych stołówkach, przedsiębiorstwa wzbraniały się „pełnić tę społeczną powinność”, argumentując, że ich stołówki znajdują się na terenie zamkniętym zakładu. Dziennikarz przypominał, że stołówki są dofinansowywane przez zakłady pracy, tym samym „do korzystania z nich uprawnieni 
są (w zasadzie) wyłącznie pracownicy danego zakładu” (WW 1980, 18: 4). Zdarzały się jednak wyjątki. W gdyńskiej stołówce Banku Inwestycyjnego o obiady „dobijali się” pracownicy wielu innych instytucji, w tym chorzy na żołądek, których właśnie do tej, słynącej ze zdrowej kuchni, placówki kierowano (DB 1956, 179: 3).

Niekiedy ze stołówek mogli też korzystać członkowie rodzin. Od lat 50. obowiązywała zasada, że priorytetem jest zaopatrzenie pracowników, a „ich rodzinom pozwalano korzystać ze stołówek tylko w tych przypadkach, gdy nie utrudniało to załodze dostępu do stołówki i nie pogarszało jakości wydawanych w niej posiłków" (Jastrząb 2004: 259). Jak to wyglądało w praktyce? W końcu lat 60. stołówkę centralną Stoczni Gdańskiej wybudowano w sąsiedztwie słynnej później Bramy nr 2, tak aby z jej oferty korzystać mogły osoby z zewnątrz (Trzeciak 2020: 129). Łódzkie włókniarki postulowały zniesienie stricte pracowniczego charakteru żywienia zakładowego i udostępnienie stołówek dla członków rodzin (Mazurek 2010: 162). Najważniejsze było dla nich spożywanie obiadów w gronie rodzinnym, miejsce - dom czy fabryka - nie miało znaczenia. Ich postulaty nie zostały jednak wysłuchane. Wśród 116 respondentów opowiadających moim studentom o jedzeniu w PRL-u zaledwie kilkoro $\mathrm{z}$ nich wspomina wspólne rodzinne obiady spożywane w zakładowych stołówkach, przy czym w dwóch przypadkach chodzi tu o jadłodajnie nietypowe: kasyno wojskowe i stołówkę Politechniki Gdańskiej. Częściej słyszymy o zabieraniu obiadów do domu w tzw. trojaczkach, połączonych wspólną rączką aluminiowych pojemnikach na poszczególne dania. Ślady wspólnego stołowania się $\mathrm{w}$ pracy znajdujemy w wybrzeżowej prasie. W konkursie na najlepszą stołówkę na Pomorzu w 1978 roku wśród zamieszczonych opinii czytelników znalazł się postulat, aby wydłużyć godziny otwarcia konkretnej placówki, „ponieważ rodziny pracowników często nie zdążają na obiad" (WW 1978, 119: 4).

Pracownicy zaspokajali głód w godzinach pracy także na inne sposoby. W latach 70. coraz bardziej popularne były bufety zakładowe. Od 1963 roku w zakładach, w których panowały uciążliwe warunki pracy, wydawano też tzw. posiłki regeneracyjne, czyli „zupy z wkładką” albo - jak głosiła ministerialna instrukcja - ,jednodaniowe, wysokokalorycznego posiłki gorące dostarczane w czasie przerw bezpośrednio do stanowiska pracy" (Czekalski 2011: 81). Miały one zapewniać robotnikowi zastrzyk 700-1000 kalorii i jednocześnie nie dezorganizować procesu produkcji. Posiłki takie najczęściej przygotowywane były przez centralną stołówkę, choć respondentka pracująca w barze mlecznym opowiadała, że właśnie tam, w obiekcie gastronomii otwartej, zaopatrywała się w zupy i wkładkę (kiełbasę, mięso, boczek) oraz chleb jedna z trójmiejskich stoczni. Pracownikom zatrudnionym w szkodliwych dla zdrowia warunkach przysługiwały też mleko i mięta, szczególnie przydatna w przemyśle hutniczym.

Wiele zakładów pracy, zwłaszcza tych mniejszych, nieposiadających własnej stołówki, zapewniało swoim pracownikom jedzenie „na mieście”. Wydawano im specjalne talony, na które - często za symboliczną dopłatą - mogli oni otrzymać obiad w wybranych barach lub restauracjach. Podobne zasady obowiązywały w przypadku 
pracowników przebywających w delegacji - mogli oni korzystać z gastronomii otwartej na koszt zakładu. W Nowej Hucie zaś to stołówki często „wychodziły na miasto”, poza obręb murów kombinatu. „W początkowych realiach nowohuckich stołówki pracownicze mieściły się na terenie obozowisk junaków Służby Polsce, a z czasem w hotelach robotniczych" (Wąchała-Skindzier 2017: 41). W 1969 roku na osiedlu Złotej Jesieni powstała nowoczesna, modernistyczna stołówka, nagrodzona w architektonicznym konkursie „Mister Krakowa” (Smaga 2017: 118).

\section{Przestrzeń stołówki}

W wielu przekazach, nie tylko tych wspomnieniowych, ale i publikowanych na łamach oficjalnej, cenzurowanej wszak prasy, wnętrze stołówki jawiło się jako przestrzeń odpychająca, nieestetyczna, brudna. Stołówka taka wytwarzała swoistą „przestrzeń węchową", o której w swoich typologiach przestrzeni wspomina Edward Hall (Hall 1978: 76). Nie tylko „ścierkowo-pomyjowa” woń odstraszała potencjalnych konsumentów. Niekiedy już samo wejście nastręczało niemałe problemy. W Nowej Hucie funkcjonowała „warowna stołówka”, do której trudno było dojść „z powodu zbyt głębokiego błota” (BS 1954, 52: 2). Fizyczne utrudnienia były jednak niczym wobec bariery psychicznej, o której istnieniu świadczą niektóre $\mathrm{z}$ wypowiedzi moich respondentów. Potwierdzają to też inne świadectwa. „Najgorzej oceniano stołówki przy hotelach robotniczych. Stan sanitarny budynków przeznaczonych do konsumpcji był tak odrażający, że lepiej było jeść na zewnątrz budynku” (Czekalski 2011: 80). W latach 50. redakcja „Dziennika Zachodniego” apelowała do czytelników o zgłaszanie kandydatur do konkursu na największego brudasa województwa spośród zakładów żywienia zbiorowego (Brzostek 2010: 278). W Zakładach im. Róży Luksemburg w pomieszczeniach przeznaczonych do spożywania posiłków składowano jednocześnie i myto lampy, a robotnicy zmuszeni byli jeść swoje śniadania przy parapetach. W innych zakładach spożywano je w szatni albo „pod gołym niebem”, jak w Stoczni Północnej, gdzie pewien spawacz skarżył się, że „deszcz pada w posiłki”(DB 1968, 259: 3).

Nowohucka prasa z dużą otwartością pisała o „antysanitarnych warunkach” lokali działających na terenie kombinatu. Bar mleczny przy restauracji „Hutnik” usytuowany był na przykład na „niesamowicie brudnej” klatce schodowej (BS 1952, 7: 4). Dramatycznie przedstawiał się stan „strasznego” baru mlecznego nr 2 w Zakładzie Koksowniczym: „brudne podłogi, niemyte widocznie od chwili powstania baru, czarne od brudu stoły, powykrzywiane stołki, okienko, przy którym wydaje się posiłki oblepione pozostałościami z potraw, brudny personel i wielkie roje much - wszystko to odstrasza konsumentów" (BS 1955, 127: 4). A przecież, jak zauważano, ,jest rzeczą bezsporną, że posiłek w czystym schludnym lokalu lepiej smakuje" (BS 1954,170:2). Nowohuckie stołówki były też często niedoposażone. Brakowało w nich nie tylko takich luksusów, jak papierowa serwetka czy kwiat na stole, ale nawet zwykłych krzeseł, co zmuszało robotników do spożywania obiadów na stojąco. Sytuacja nie wyglądała wcale lepiej w latach 60. - nierówna podłoga 
sprawiała, że z talerzy wylewała się zupa, na podłodze stały kałuże wody, a z powodu niedostatecznej liczby miejsc przy stole posiłki trzeba było spożywać na schodach. Na drugim biegunie znajdowały się stołówki, które stawiano jako wzór do naśladowania. Do takich należała nowohucka stołówka nr 6, „bo proszę, sala czyściutka, przyjemnie udekorowana, posadzka, stoliki” (BS 1955, 13: 2). Taka też miała być nowa, reprezentacyjna stołówka, powstająca w 1955 roku: „Malarze starannie dobierają kolory. I tak złoty ugier wewnątrz sztukaterii, okna kremowe, drzwi mahoń jasny, kuchnia jaśnieje bielą" (BS 1954, 74: 2).

W roku 1950 „Dziennik Bałtycki” w swoim omówieniu zaniedbań w portowych stołówkach podkreślał: „Spożycie smacznego posiłku w estetycznie urządzonej jadalni odpręża pracownika nie tylko fizycznie, ale i psychicznie”(DB 1950,157:2). Dziennikarze tejże gazety, badając w 1953 roku jakość stołówek w Gdyni, stwierdzali, że większość z nich znajduje się „w nieodpowiednich do tego celu pomieszczeniach”. Narzekali na złe wyposażenie, brak czystości i „wcale nie wonne zapachy kuchenne", niedodające apetytu jedzącym. Jedynym pozytywnym przykładem była wspomniana tu już stołówka Banku Inwestycyjnego w Gdyni: „Jasne, czyste ściany, gustowne stoliki i wygodne krzesła w przeciwieństwie do «warsztatowych» stołów i ław w innych tego rodzaju lokalach [...] stwarzają miłe wrażenie” (DB 1953, 15: 3). Była to zasługa kierowniczki, dzięki której „stołówka nie stała się tym, czym są prawie wszystkie zakłady tego typu - brudnym pomieszczeniem, wydającym dosyć podłe obiady po niskiej cenie [...]. Sala jadalna wesoła i przytulna - ładnie nakryte stoliki, w oknach białe firanki, dużo kwiatów. No i największa niespodzianka - to same obiady, wyjątkowo smaczne, zupełnie nie «stołówkowe»" (DB 1956, 179: 3). Tuż po wojnie powstała piosenka ze słowami: „Stołówko, stołówko, ty jesteś brzydkie słówko" (Czarna księga cenzury 1978: 38). Jak widać, nawet oficjalna prasa traktowała określenie „stołówkowe” jako słowo o wyraźnie pejoratywnym zabarwieniu. Wzorcową placówką była też centralna stołówka Stoczni Gdańskiej. Był to przestronny, przeszklony budynek o żelbetonowej, dwupoziomowej konstrukcji, z wnętrzami zdobionymi dekoracjami z topionego szkła.

\section{Zakończenie}

Przestrzeń stołówek pracowniczych pełniła wiele różnych ról, a każda z nich zasługiwałaby na osobne, pogłębione badania. Tu można tylko wskazać możliwe tropy. Przede wszystkim była to przestrzeń integracji załogi. Na stołówkach zasiadali do obiadu zarówno inżynierowie, jak i prości robotnicy, i nawet jeśli wybierali różne stoliki, łączyło ich wspólne menu (Pyszny 2007: 219). Wspólnota pracowników zakładu przejawiała się też w inny, mniej pożądany przez decydentów sposób: „bufety zakładowe były nie tylko miejscem konsumpcji, ale także stwarzały okazję do nieformalnej komunikacji, do rozmów o kłopotach zaopatrzeniowych. Zakład pracy stanowił naturalną przestrzeń do - społeczną i integrującą" (Mazurek 2010: 165). Niekiedy jednak zrywano z tą zasadą. W Nowej Hucie powstało luksusowe kasyno, w którym podejmowano oficjeli najwyższego szczebla. W 1983 roku w stołówce Stoczni Gdańskiej w tym samym celu 
stworzono osobne wejście ze schodami poprowadzonymi od tyłu budynku, a dla partyjnych gości zamawiano catering w luksusowej restauracji „Pod Łososiem” (Daszczyńska, Kobzdej 2013: 46).

Stołówki pełniły też funkcje socjalne, to tu miały miejsce spotkania robotników, bale sylwestrowe i karnawałowe, obchody Dnia Kobiet i świąt branżowych. W stołówce Stoczni im. Lenina odbywały się również wystawy sztuki, kiermasze, działał punkt biblioteczny (Miler, Stormowska). Na ścianach stołówek, obok widoczków miast, pojawiały się też hasła propagandowe, których treści żaden ze 116 respondentów nie potrafił sobie jednak przypomnieć.

Stołówki stawały się też niekiedy przestrzenią polityczną, miejscem buntu przeciw komunistycznej władzy. Szczególnie burzliwe są losy stołówki centralnej Stoczni im. Lenina, w której podczas strajków sierpniowych magazynowano dary żywnościowe dla strajkujących i wydawano ciepłe posiłki członkom straży strajkowej (Miler, Stormowska). 13 grudnia 1981 roku ze stołówki zrobiono sypialnię (Gluza 1991: 42). W dzień obradował w niej komitet strajkowy, a w kuchni przygotowywano posiłki nie tylko dla obrońców stoczni, ale i dla oblegających ją żołnierzy (Leczkowska 1999: 181). Na dzień przed pacyfikacją stołówka zamieniła się w przestrzeń sakralną - odprawiono w niej mszę (Trzeciak 2020: 129).

Niezależnie od propozycji dalszych badań już teraz można pokusić się o kilka wniosków. Wydaje się, że stołówki nie alienowały swoich użytkowników z przestrzeni publicznej. Wykupienie obiadów w zakładzie pracy nie było równoznaczne z rezygnacją z gastronomii otwartej. Kelnerka nowohuckiej restauracji „Wisła”, Zofia Maślak opowiadała mi, że niegdysiejsza klientela funkcjonującej obok restauracji pijalni wódki i piwa rekrutowała się z hutników, „robociarzy w przepoconych kombinezonach”, którzy zaraz po pracy w Hucie szli zjeść swoje ulubione danie, a przede wszystkim napić się alkoholu, co nie było możliwe w stołówkach, które z zasady nie prowadziły wyszynku. Jak ocenia Tadeusz Czekalski, „w dużych miastach stołówki nie były w stanie zagrozić obiektom gastronomii otwartej, zwłaszcza barom szybkiej obsługi”(Czekalski 2011: 80). Stołówka nie musiała też stać w kolizji z rodzinnym spożywaniem posiłków. Wręcz przeciwnie - dzięki wynalazkowi „trojaczków” ułatwiała zorganizowanie domowego obiadu. Przestrzeń zakładowej stołówki zazwyczaj nie zachęcała do konsumpcji. „W przeciwieństwie do innych krajów bloku, polskie stołówki były niewielkie i stale zatłoczone, a ceny posiłków stosunkowo wysokie. W zdecydowanej większości tego typu obiektów nie sposób było rozwiązać problemu właściwej wentylacji” (Czekalski 2011: 82). W końcu lat 60. powstawały co prawda duże, nowoczesne, modernistyczne w formie jadłodajnie zakładowe, takie jak stołówka centralna w Stoczni Gdańskiej albo stołówka na osiedlu Złotej Jesieni w Nowej Hucie, ale były to dość rzadkie inwestycje. Projekt ideologiczny, w którym stołówka miała być jednym z elementów wiążących pracownika $\mathrm{z}$ zakładem pracy i tworzących przestrzeń alternatywną wobec miasta, $\mathrm{z}$ wielu względów się nie powiódł. 


\section{Bibliografia}

Bierwiaczonek K. 2016. Spoteczne znaczenie miejskich przestrzeni publicznych. Katowice: Wydawnictwo Uniwersytetu Śląskiego.

Brzostek B. 2010. PRL na widelcu. Warszawa: Baobab.

Czarna ksiega cenzury PRL 1978. T. 2. Londyn: Aneks.

Czekalski T. 2011. Przedsiębiorstwa żywienia zbiorowego w realiach PRL: model żywienia zbiorowego w warunkach przyspieszonej modernizacji i jego realizacja. Annales Universitatis Paedagogicae Cracoviensis. Studia Politologica 5, 78-90.

Daszczyńska H. i Kobzdej D. (red.) 2013. Tu Stocznia. Gdańsk: Fundacja Centrum Solidarności. Drzał-Sierocka A. 2018. Jedzenie taśmowe? Dzisiejsze czasy Chaplina jako głos w dyskusji na temat idei fast food. [W:] A. Kamler, D. Pietrzkiewicz, K. Seroka (red.), Polska i świat przez kuchnię. Studia o dziedzictwie kulinarnym. Warszawa: Grupa Cogito.

Gluza Z. (red.) 1991. W stanie. Warszawa: Wydawnictwo „Karta”.

Głuszczenko I.2012. Sowiety od kuchni. Mikojan i radziecka gastronomia. Warszawa: Wydawnictwo Krytyki Politycznej.

Hall E. T. 1978, Ukryty wymiar. Warszawa: Państwowy Instytut Wydawniczy.

Jarska N. 2015. Kobiety z marmuru. Robotnice w Polsce w latach 1945-1960. Warszawa: Instytut Pamięci Narodowej.

Jastrząb M. 2004. Puste pótki. Problem zaopatrzenia ludności w artykuty powszechnego użytku w Polsce w latach 1949-1956. Warszawa: Wydawnictwo Wyższa Szkoła Przedsiębiorczości i Zarządzania im. L. Koźmińskiego.

Leczkowska J. 1999. Ciężkie sytuacje ludzi zbliżają, otwierają ich serca [W:] J. Kulas (red.), Stan wojenny. Wspomnienia i oceny. Pelplin: Bernardinum, 181-184.

Mazurek M. 2005. Socjalistyczny zaktad pracy. Porównanie fabrycznej codzienności w PRL i NRD u progu lat sześćdziesiątych. Warszawa: Wydawnictwo „Trio”.

Mazurek M. 2010. Społeczeństwo kolejki. O doświadczeniach niedoboru 1945-1989. Warszawa: Wydawnictwo „Trio”.

Miler A. i Stormowska M. b.r.w. Stocznia gdańska szlakami kobiet (ulotka), Gdańsk: Instytut Kultury Miejskiej.

Pyszny J. 2007. Co jada bohater? Kod kulinarny literatury socrealistycznej, czyli dieta a światopogląd [W:] K. Łeńska-Bąk (red.), Pokarmy i jedzenie w kulturze. Tabu, dieta, symbol. Opole: Wydawnictwo Uniwersytetu Opolskiego, 215-245.

Smaga M. 2017. „Stylowa”, „Arkadia”, „Mozaika”... - wnętrza lokali gastronomicznych w Nowej Hucie z okresu PRL. [W:] M. Baran, Bufet pod Kombinatem, Kraków: Muzeum Historyczne Miasta Krakowa, 87-125.

Trzeciak A. 2020. Stocznia Gdańska. Miejsca, ludzie, historie. Gdańsk: Europejskie Centrum Solidarności.

Wąchała-Skindzier M. 2017. Miasto socjalistyczne na widelcu, czyli rzecz o nowohuckich lokalach gastronomicznych. [W:] M. Baran, Bufet pod Kombinatem, Kraków: Muzeum Historyczne Miasta Krakowa, 37-85. 
Autorka:

Dr Monika Milewska

Instytut Archeologii i Etnologii

Uniwersytet Gdański

ul. Bielańska 5, 80-851 Gdańsk

e-mail: monika.milewska@ug.edu.pl 